\title{
PROPERTIES OF 15Cr12WNiMoV STEEL AFTER VACUUM ACTIVATED CHROMIUM PLATING OF ITS SURFACE
}

\author{
S.G. Rudenky, N.F. Kartzev, A.A. Korneev, A.V. Kunchenko, Y.V. Kunchenko, \\ V.G. Marinin, L.I. Martynenko, V.I.Kovalenko, M.O.Bortnytska, T.P. Ryzhova, \\ I.A. Lashenko, S. V. Gozhenko, Y.A. Krainyuk \\ National Science Center "Kharkov Institute of Physics and Technology", Kharkiv, Ukraine \\ E-mail: martynenko@ kipt.kharkov.ua; tel.+38(057)335-63-98
}

In this work, we studied the properties of samples from steel $15 \mathrm{Cr} 12 \mathrm{WNiMoV}$ after vacuum activated chromium plating at temperatures of 1070 and $1100{ }^{\circ} \mathrm{C}$ for 4 and $10 \mathrm{~h}$. It was found that after chemical-thermal treatment on the samples a diffusion layer with a thickness of 50 to $130 \mu \mathrm{m}$ is formed, consisting of $56 \ldots 82 \mathrm{wt} . \%$ of chromium, the rest is iron. Metallographic studies were carried out on the samples and tests for heat resistance were carried out at a temperature of $T=900{ }^{\circ} \mathrm{C}$. It was found that chrome-plated samples significantly exceed the initial samples and nitrided ones in terms of heat resistance. Tests of samples for tensile strength after chromium plating showed a significant increase in strength indicators for ultimate strength and yield strength. The plasticity characteristics of these samples are reduced.

\section{INTRODUCTION}

The current state of the turbine industry requires constant improvement of the materials used in this industry. One of the ways to improve the characteristics of materials is the use of protective coatings. Steel $15 \mathrm{Cr} 12 \mathrm{WNiMoV}$ is widely used in industry, in particular, in mechanical engineering. This steel grade is used as a material for turbine parts manufactured at public joint-stock company "Turboatom". It is impossible to predict which coating, as well as the method of its formation, can positively affect the quality of products from this steel grade. This requires practical research.

Considering that steam turbine parts usually operate under conditions of high temperatures and mechanical destructive loads, it is necessary, first of all, to increase the heat resistance of the product surface. One of the elements that are heat-resistant and significantly increase the corrosion resistance of alloys is chromium. As shown by the data of numerous studies, starting with the monograph [1], at present, research continues on various methods of chromium plating and materials that are processed [2-5]. We use the method of vacuum activated diffusion saturation for chromium plating of metal and alloy products [6,7]. When this chemicalthermal treatment is carried out in sodium chloride vapor, an environmentally friendly process takes place.

Our earlier studies on the chromium plating of samples from unalloyed steels of grade St.3, St.20, St.45 and U8 showed that when processing these materials, a diffusion layer is formed, consisting of chromium carbides $\mathrm{Cr}_{23} \mathrm{C}_{6}, \mathrm{Cr}_{7} \mathrm{C}_{3}$, and a solid solution of this element in iron [8]. The process of formation of a diffusion layer occurs through the formation of a gaseous saturating medium consisting of lower chromium chlorides.

In the case of diffusion chromium plating of the surface of $25 \mathrm{Cr} 1 \mathrm{MoV}$ steel, it leads to the formation of a surface layer containing from 87 to $97 \mathrm{wt} . \%$ of this element [9]. It was found that an increase in the temperature of the process and its duration leads to an increase in the chromium content on the surface of the samples. The tests carried out on the effect of cavitation-erosion and mechanical wear on the surface of steel $25 \mathrm{Cr} 1 \mathrm{MoV}$ show that chemical-thermal treatment increases the resistance of this material. The aim of this work is to study the characteristics of $15 \mathrm{Kh} 12 \mathrm{VNMF}$ steel after vacuum activated chromium plating of its surface. To establish the dependence of the influence of the parameters of the chromium plating process on the heat resistance and mechanical strength of specimens from this steel.

\section{MATERIALS AND RESEARCH METHODS}

Round washers made of $15 \mathrm{Cr} 12 \mathrm{WNiMoV}$ steel with a diameter of $18 \mathrm{~mm}$ and a thickness of $4 \mathrm{~mm}$ were used as samples for chrome plating and subsequent studies. In the comparative tests, we used samples of 15Cr12WNiMoV steel, which had been furnace nitrided at public joint-stock company "Turboatom". These samples were tested for resistance to cavitation using the vibration method. The NSC KIPT developed a stand for creating cavitation [10]. Abrasive mechanical wear was investigated using an ABI-1 unit. The wear was carried out according to the plane-disk scheme. The speed of movement of the disk surface in contact with the plane of the sample is $4.38 \mathrm{~m} / \mathrm{s}$, and the load on the sample is $2.2 \mathrm{~N}$. The wear rate was determined by measuring the weight loss of the sample over a fixed time. The chemical composition of the surface of the samples was determined by X-ray fluorescence analysis using an SPRUT device. The structural composition of the chrome-plated surface was determined by X-ray diffraction analysis using a DRON-3 device. The structure of the samples after chemical-thermal treatment was studied by metallographic analysis. Heat resistance tests of the samples were carried out in air in a muffle furnace. Mechanical tests were carried out on 
an INSTRON-5581 electromechanical machine using a strain gauge with a maximum load of $50 \mathrm{kN}$.

\section{RESULTS AND ITS DISCUSSION}

In this work, we investigated the surface composition of $15 \mathrm{Cr} 12 \mathrm{WNiMoV}$ steel after chemical thermal treatment. Table 1 shows the results of investigating the surface of $15 \mathrm{Cr} 12 \mathrm{WNiMoV}$ steel after its chemical-thermal treatment. The chemical composition of the surface was determined by was determined by X-ray fluorescence analysis.

Table 1

Chemical composition of the $15 \mathrm{Cr} 12 \mathrm{WNiMoV}$ steel surface after chromium plating

\begin{tabular}{|c|c|c|c|c|c|c|c|c|c|c|c|c|c|}
\hline Material & \multicolumn{13}{|c|}{ Mass fraction of elements, wt. $\%$} \\
\hline Steel & $\mathrm{C}$ & $\mathrm{Si}$ & $\mathrm{Mn}$ & $\mathrm{Ni}$ & $\mathrm{S}$ & $\mathrm{P}$ & $\mathrm{Cr}$ & Mo & $\mathrm{W}$ & $\mathrm{V}$ & $\mathrm{Ti}$ & $\mathrm{Cu}$ & $\mathrm{Fe}$ \\
\hline $\begin{array}{l}15 \mathrm{H} 12 \mathrm{VNMF} \\
\text { according to } \\
\text { state standard }\end{array}$ & $\begin{array}{c}0.12- \\
0.18\end{array}$ & $\begin{array}{c}< \\
0.40\end{array}$ & $\begin{array}{r}0.50- \\
0.90\end{array}$ & $\begin{array}{c}0.40- \\
0.80\end{array}$ & $\begin{array}{c}< \\
0.025\end{array}$ & $\begin{array}{c}< \\
0.03\end{array}$ & $\begin{array}{l}11.0- \\
13.0\end{array}$ & $\begin{array}{c}0.50- \\
0.70\end{array}$ & $\begin{array}{l}0.70- \\
1.10\end{array}$ & $\begin{array}{c}0.15- \\
0.30\end{array}$ & $\begin{array}{l}\text { Up } \\
\text { to } \\
0.2\end{array}$ & $\begin{array}{c}< \\
0.30\end{array}$ & $\sim 83$ \\
\hline $\begin{array}{c}\text { Initial } \\
\text { steel }\end{array}$ & - & 0.8 & 0.9 & 0.5 & - & - & 11.2 & - & 0.7 & - & - & 0.5 & 85.4 \\
\hline $\begin{array}{c}\text { Nitrided } \\
\text { steel }\end{array}$ & - & 0.2 & 0.5 & 0.5 & - & - & 9.9 & 0.7 & - & - & - & - & 88.5 \\
\hline $\begin{array}{c}\text { Chrome steel: } \\
T=1070^{\circ} \mathrm{C}, \\
6 \mathrm{~h}\end{array}$ & - & 0.1 & - & - & - & - & 64.3 & 0.8 & - & - & - & - & 34.7 \\
\hline $\begin{array}{c}\text { chrome steel: } \\
T=1070^{\circ} \mathrm{C} \\
10 \mathrm{~h}\end{array}$ & - & - & - & - & - & - & 82.9 & 0.6 & - & - & - & 0.3 & 16.1 \\
\hline $\begin{array}{c}\text { Chrome steel: } \\
T=1100^{\circ} \mathrm{C}, \\
4 \mathrm{~h}\end{array}$ & - & - & - & - & - & - & 59 & - & - & - & - & - & 41 \\
\hline $\begin{array}{c}\text { Chrome steel: } \\
T=1100{ }^{\circ} \mathrm{C} \\
10 \mathrm{~h}\end{array}$ & - & 0.3 & - & - & - & - & 76 & 0.6 & - & - & - & - & 23 \\
\hline
\end{tabular}

*Samples had been furnace nitrided at public joint-stock company "Turboatom".

The results presented in Table 1 show the results in the storage of surfaces from steel 15X12VNMF, which drastically changes the warehouse of surfaces. Alloying additives present in the original steel according to state standard practically disappear from the surface layer. As follows from the results given in the table, the chromium concentration in the surface layer changes depending on the chromium plating temperature. During vacuum chemical-thermal treatment, two parallel processes take place - the precipitation of chromium in the surface layer and its diffusion into the interior of the steel. As a result, although with an increase in the temperature of the process, there is an increase in the release of chromium, but the rate of diffusion processes also increases. This leads to a lower concentration of chromium in the surface layer of the steel at a higher temperature of the chemical heat treatment process.

Below are photographs of the microstructure of the cross section of the samples after vacuum chromium plating (Fig. 1).

On a special stand, comparative studies of the samples for resistance to cavitation created using the vibration method were carried out.

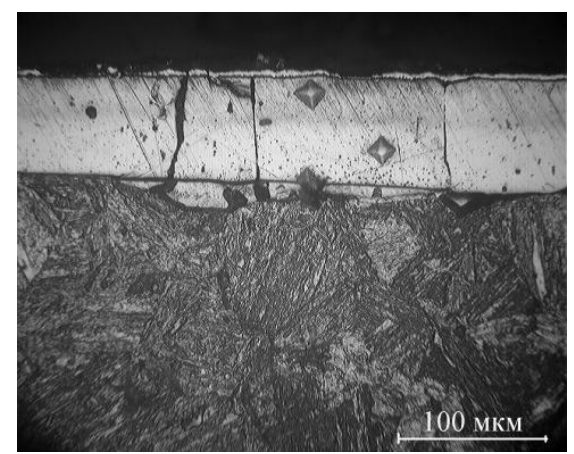

$a$

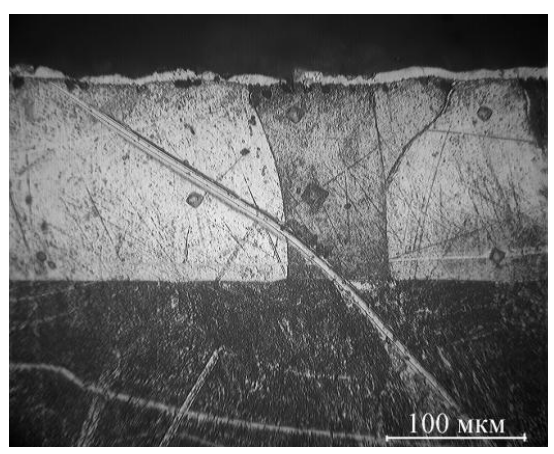

$b$

Fig. 1. A photograph of a thin section of specimens made of steel $15 \mathrm{Cr} 12 \mathrm{WNiMoV}$,

which were chrome-plated: $a$-at a temperature of $1070{ }^{\circ} \mathrm{C}, 4 \mathrm{~h} ; \mathrm{b}$-at a temperature of $1070{ }^{\circ} \mathrm{C}, 10 \mathrm{~h}$.

Depending on the temperature of chemical-thermal treatment in the range of $1070 \ldots 1100^{\circ} \mathrm{C}$ and its duration of $4 \ldots 10 \mathrm{~h}$, the thickness of the diffusion layer varies from 50 to $130 \mu \mathrm{m}$ 


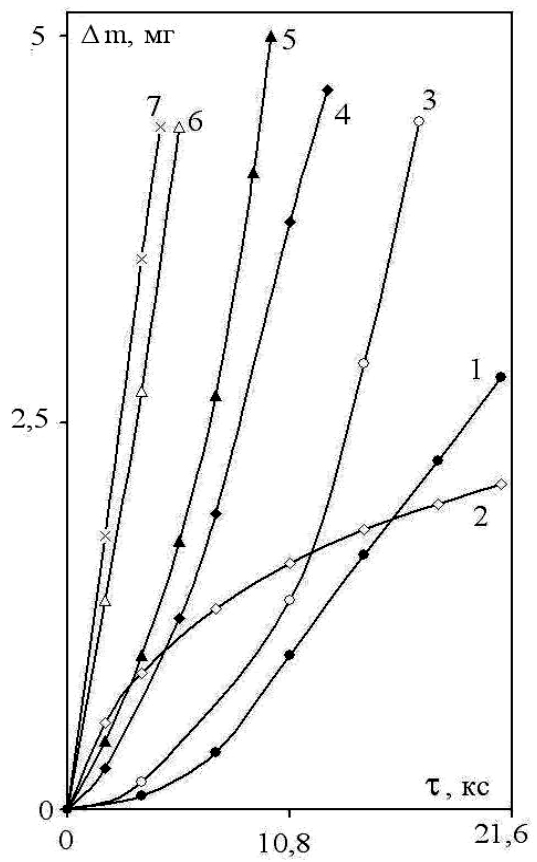

Fig. 2. Kinetic curves of cutting of steel 15Cr12WNiMoV at the stage of cavitation: 1 -without processing; 2 -food for food nitrogen; 3 - 7-chrome wash at low temperatures and hour: $3-T=1343 \mathrm{~K}, t=14.4 \mathrm{ks}$;

$4-T=1373 \mathrm{~K}, t=14.4 \mathrm{ks} ; 5-T=1373 \mathrm{~K}, t=21.6 \mathrm{ks}$ $6-T=1343 \mathrm{~K}, t=36.0 \mathrm{ks} ; 7-T=1373 \mathrm{~K}, t=36.0 \mathrm{ks}$

The results of the incidence of abrasion and cavitation are given in Table 2.

Table 2

Wear of $15 \mathrm{Cr} 12 \mathrm{WNiMoV}$ steel for abrasive and cavitation

\begin{tabular}{|c|c|c|c|c|c|c|c|c|}
\hline \multirow{2}{*}{\multicolumn{2}{|c|}{$\begin{array}{c}\text { Sample numbers } \\
\text { corresponding to curve numbers } \\
\begin{array}{c}\text { Sample numbers during } \\
\text { processing }\end{array}\end{array}$}} & 1 & 2 & 3 & 4 & 5 & 6 & 7 \\
\hline & & 35 & 36 & 10 & $20-\mathrm{A}_{1}$ & $20-\mathrm{A}_{2}$ & 46 & 53 \\
\hline \multirow[t]{2}{*}{$\begin{array}{l}\text { Processing } \\
\text { parameters }\end{array}$} & $\begin{array}{c}\text { temperature } \\
T, \mathrm{~K}\end{array}$ & $\begin{array}{c}\text { without } \\
\text { processing }\end{array}$ & $\begin{array}{l}\text { furnace } \\
\text { nitriding }\end{array}$ & 1343 & 1373 & 1373 & 1343 & 1373 \\
\hline & $\begin{array}{l}\text { time } \\
t, \mathrm{ks}\end{array}$ & - & - & 14.4 & 14.4 & 21.6 & 36.0 & 36.0 \\
\hline $\begin{array}{l}\text { Destruction } \\
\text { rate when } \\
\text { exposed to } \\
\text { abrasive }\end{array}$ & $\mathrm{mg} / \mathrm{ks}$ & 3.6 & 8.2 & 9.09 & 12.12 & 8.5 & 8.4 & 4.5 \\
\hline $\begin{array}{l}\text { Destruction } \\
\text { rate when } \\
\text { exposed to } \\
\text { cavitation }\end{array}$ & $\mu \mathrm{m} / \mathrm{ks}$ & 0.43 & 0.1 & 0.938 & 1.19 & 0.156 & 1.85 & 1.69 \\
\hline
\end{tabular}

The curves shown in Fig. 2 allow expressing a certain opinion. Kinetic curves 1, 2 have the same form, while others differ depending on the parameters of the chromium plating process. These are curves describing the process of destruction of samples of the initial steel and steel, which has passed the furnace nitriding at the enterprise. The remaining curves 3-7 describe the destruction of samples that have undergone vacuumactivated chromium plating. As follows from the data in Table 1, the surface layer having a high chromium concentration is inferior in resistance to the original steel.

Table 2 shows the results of wear of steel samples from cavitation and abrasive. In this table, samples 1 and 2 are respectively original and nitrided. These samples are superior in resistance to cavitation and abrasion wear of all samples that have undergone vacuum chrome plating. Chromium plating of samples changes their resistance to cavitation and abrasives, while the rate of destruction depends on the process parameters (temperature and time). Therefore, it may be necessary to select the parameters of the chromium plating regime in order to preserve the resistance of the samples when exposed to cavitation and abrasive wear.

Investigations were carried out on the effect of vacuum activated diffusion chromium plating of the surface of $15 \mathrm{Cr} 12 \mathrm{WNiMoV}$ steel on the heat resistance of this material. Comparative tests were carried out in air at temperatures of 700,900 , and $1100{ }^{\circ} \mathrm{C}$. In these tests, the initial sample, nitrided, and the samples, chrome-plated with different processing parameters, were simultaneously placed in a ceramic boat. Table 3 below shows the results of tests for heat resistance at a temperature of $T=900{ }^{\circ} \mathrm{C}$. 
Tests of specimens from steel $15 \mathrm{Cr} 12 \mathrm{WNiMoV}$ for heat resistance in air at temperature $T=900{ }^{0} \mathrm{C}$, total duration $15.5 \mathrm{~h}$

\begin{tabular}{|c|c|c|c|c|}
\hline No & Material, processing & Sample weight, $g$ & $\begin{array}{l}\text { Change in sample } \\
\text { weight, } g\end{array}$ & $\begin{array}{l}\text { Total change in } \\
\text { sample weight, } g\end{array}$ \\
\hline \multirow[t]{4}{*}{1} & \multirow{4}{*}{$\begin{array}{c}\text { Steel } 15 \mathrm{Cr} 12 \mathrm{WNiMoV}, \\
\text { initial steel }\end{array}$} & $\mathrm{P}_{0}=4.50705$ & & \multirow[t]{4}{*}{$0.04995^{*}$} \\
\hline & & $\mathrm{P}_{7}=4.50965$ & $\Delta \mathrm{P}_{1}=0.0026$ & \\
\hline & & $\mathrm{P}_{5.5}=4.54700$ & $\Delta \mathrm{P}_{2}=0.03735$ & \\
\hline & & $\mathrm{P}_{3}=4.51160$ & $\Delta \mathrm{P}_{3}=-0.03540$ & \\
\hline \multirow[t]{4}{*}{2} & \multirow{4}{*}{$\begin{array}{c}\text { Steel } 15 \mathrm{Cr} 12 \mathrm{WNiMoV}, \\
\text { nitrided steel }\end{array}$} & $\mathrm{P}_{0}=4.45360$ & & \multirow[t]{4}{*}{$0.09700 *$} \\
\hline & & $\mathrm{P}_{7}=4.49965$ & $\Delta \mathrm{P}_{1}=0.04605$ & \\
\hline & & $P_{5.5}=4.55060$ & $\Delta \mathrm{P}_{2}=0.05095$ & \\
\hline & & $\mathrm{P}_{3}=4.40180$ & $\Delta \mathrm{P}_{3}=-0.14880$ & \\
\hline \multirow[t]{4}{*}{3} & \multirow{4}{*}{$\begin{array}{c}\text { Steel } 15 \mathrm{Cr} 12 \mathrm{WNiMoV}, \\
\text { chrome steel: } \\
T=1070{ }^{0} \mathrm{C}, 4 \mathrm{~h}\end{array}$} & $\mathrm{P}_{0}=4.51880$ & & \multirow[t]{4}{*}{0.00085} \\
\hline & & $\mathrm{P}_{3.5}=4.51910$ & $\Delta \mathrm{P}_{1}=0.00030$ & \\
\hline & & $\mathrm{P}_{3.5}=4.51960$ & $\Delta \mathrm{P}_{2}=0.00050$ & \\
\hline & & $\mathrm{P}_{4.5}=4.51965$ & $\Delta \mathrm{P}_{3}=0.00005$ & \\
\hline \multirow[t]{5}{*}{4} & \multirow{5}{*}{$\begin{array}{c}\text { Steel } 15 \mathrm{Cr} 12 \mathrm{WNiMoV}, \\
\text { chrome steel: } \\
T=1070{ }^{0} \mathrm{C}, 10 \mathrm{~h}\end{array}$} & $\mathrm{P}_{0}=4.56900$ & & \multirow[t]{5}{*}{0.00055} \\
\hline & & $P_{3.5}=4.56920$ & $\Delta \mathrm{P}_{1}=0.00020$ & \\
\hline & & $P_{3.5}=4.56935$ & $\Delta \mathrm{P}_{2}=0.00015$ & \\
\hline & & $\mathrm{P}_{4.5}=4.56940$ & $\Delta \mathrm{P}_{3}=0.00005$ & \\
\hline & & $\mathrm{P}_{4}=4.56955$ & $\Delta \mathrm{P}_{4}=0.00005$ & \\
\hline \multirow[t]{4}{*}{5} & \multirow{4}{*}{$\begin{array}{c}\text { Steel } 15 \mathrm{Cr} 12 \mathrm{WNiMoV}, \\
\text { chrome steel: } \\
T=1100{ }^{0} \mathrm{C}, 4 \mathrm{~h}\end{array}$} & $\mathrm{P}_{0}=4.54020$ & & \multirow[t]{4}{*}{0.00145} \\
\hline & & $\mathrm{P}_{3.5}=4.54085$ & $\Delta \mathrm{P}_{1}=0.00065$ & \\
\hline & & $P_{3.5}=4.54145$ & $\Delta \mathrm{P}_{2}=0.00060$ & \\
\hline & & $\mathrm{P}_{4.5}=4.54165$ & $\Delta \mathrm{P}_{3}=0.00020$ & \\
\hline \multirow[t]{5}{*}{6} & \multirow{5}{*}{$\begin{array}{c}\text { Steel } 15 \mathrm{Cr} 12 \mathrm{WNiMoV}, \\
\text { chrome steel: } \\
T=1100{ }^{0} \mathrm{C}, 10 \mathrm{~h}\end{array}$} & $\mathrm{P}_{0}=4.60030$ & & \multirow[t]{5}{*}{0.00018} \\
\hline & & $\mathrm{P}_{3.5}=4.60055$ & $\Delta \mathrm{P}_{1}=0.00015$ & \\
\hline & & $P_{3.5}=4.60080$ & $\Delta \mathrm{P}_{2}=0.00025$ & \\
\hline & & $\mathrm{P}_{4.5}=4.60100$ & $\Delta \mathrm{P}_{3}=0.00020$ & \\
\hline & & $\mathrm{P}_{4}=4.600120$ & $\Delta \mathrm{P}_{4}=0.00020$ & \\
\hline
\end{tabular}

*In these cases, the total weight change was reported in $12.5 \mathrm{~h}$.

In the Table in the third capital, $\mathrm{P} \tau$ is the weight of the sample, where $\tau$ is the time of testing.

Based on the data presented in Table 3, certain conclusions can be drawn. The change in weight for the original samples is about $0.5 \mathrm{~g}$, and the nitrided samples have changed in weight by half. The change in weight of chrome-plated samples is much less - it ranges from 0.0002 to $0.00145 \mathrm{~g}$. This means that the heat resistance of chrome-plated specimens is much higher than that of the original specimens and those that have undergone nitriding.

Tests of samples made of $15 \mathrm{Cr} 12 \mathrm{WNiMoV}$ steel for rupture and bending were carried out.

The results presented in Table 4 show that the initial samples have satisfactory characteristics in comparison with the data for this steel given in according to state standard 19442-74. More precisely, the average value of the conventional yield stress for the initial samples is approximately at the same level. The average tensile strength of the metal of the original samples exceeds the values given in according to state standard 19442-74 for this steel by about $130 \mathrm{MPa}$ and reaches $864 \mathrm{MPa}$. With respect to elongation $(\delta, \%)$ for the steel of the initial samples, it is close to the values of according to state standard 19442-74. However, the relative narrowing $(\psi, \%)$ has a higher value by $5 \ldots 10 \%$.

The obtained data for nitrided specimens in terms of strength characteristics are comparable with the value for the original specimens. According to the average value, the yield stress for nitrided samples is lower by about $70 \mathrm{MPa}$ and is equal to about $623 \mathrm{MPa}$. At the same time, the ultimate strength remains approximately at the same level as the original samples - $823 \mathrm{MPa}$. The plasticity characteristics of nitrided samples compared with the original ones are $2-3$ times less for $(\delta, \%)$ and $3-3.5$ times for $(\psi, \%)$. During the tests, all nitrided samples collapsed without necking, which indicates the absence of significant deformation at the fracture site. The plane of destruction has two zones: the core and the outer circle. Probably, this can be associated with the process of chemical-thermal treatment of the metal. 
Table 4

Tensile strength test of $15 \mathrm{Cr} 12 \mathrm{WNiMoV}$ steel specimens at room temperature

\begin{tabular}{|c|c|c|c|c|c|c|c|}
\hline Series & Processing & $\begin{array}{l}\text { No. } \\
\text { sample }\end{array}$ & $\begin{array}{c}\text { Label } \\
\text { on ample }\end{array}$ & $\begin{array}{l}\sigma_{0.2} \\
\mathrm{MPa}\end{array}$ & $\begin{array}{c}\sigma_{\mathrm{B}} \\
\mathrm{MPa}\end{array}$ & $\delta, \%$ & $\Psi, \%$ \\
\hline \multirow[t]{16}{*}{ TP17-565 } & \multirow[t]{4}{*}{ Original } & 1 & 1 & 709 & 800 & 13.2 & 61 \\
\hline & & 2 & 2 & 682 & 807 & 12.5 & 58 \\
\hline & & 3 & 3 & 701 & 831 & 13.3 & 54 \\
\hline & & \multicolumn{2}{|c|}{ average } & 697 & 813 & 13 & 58 \\
\hline & \multirow[t]{4}{*}{ Nitrided } & 4 & 1 & 616 & 806 & 4.2 & 14,4 \\
\hline & & 5 & 2 & 613 & 809 & 4.6 & 14,4 \\
\hline & & 6 & 3 & 640 & 853 & 5.0 & 14,4 \\
\hline & & \multicolumn{2}{|c|}{ average } & 623 & 823 & 4.6 & 14.4 \\
\hline & \multirow{4}{*}{$\begin{array}{l}\text { Chrome steel: } \\
T=1100^{\circ} \mathrm{C}, 4 \mathrm{~h}\end{array}$} & 7 & 1 & 848 & 1117 & 6.4 & 47 \\
\hline & & 8 & 2 & 859 & 1135 & 7.6 & 47 \\
\hline & & 9 & 3 & 822 & 1112 & 7.4 & 47 \\
\hline & & \multicolumn{2}{|c|}{ average } & 843 & 1121 & 7.1 & 47 \\
\hline & \multirow{4}{*}{$\begin{array}{l}\text { Chrome steel: } \\
T=1100^{\circ} \mathrm{C}, 10 \mathrm{~h}\end{array}$} & 10 & 1 & 849 & 1147 & 10.0 & 54 \\
\hline & & 11 & 2 & 876 & 1198 & 11.1 & 48 \\
\hline & & 12 & 3 & 875 & 1116 & 6.1 & 52 \\
\hline & & \multicolumn{2}{|c|}{ average } & 867 & 1154 & 9.1 & 51 \\
\hline \multirow{12}{*}{$\begin{array}{l}\text { TP17- } \\
565^{* *}\end{array}$} & \multirow[t]{4}{*}{ Original } & 1 & 1 & 712 & 832 & 12.0 & 61 \\
\hline & & 2 & 2 & 721 & 833 & 10.9 & 58 \\
\hline & & 3 & 3 & 734 & 858 & 12.6 & 60 \\
\hline & & \multicolumn{2}{|c|}{ average } & 722 & 841 & 11.8 & 60 \\
\hline & \multirow{4}{*}{$\begin{array}{l}\text { Chrome steel: } \\
T=1070{ }^{\circ} \mathrm{C}, 4 \mathrm{~h}\end{array}$} & 4 & 1 & 897 & 1206 & 7.9 & 44 \\
\hline & & 5 & 2 & 910 & 1185 & 6.2 & 45 \\
\hline & & 6 & 3 & 900 & 1199 & 7.6 & 45 \\
\hline & & \multicolumn{2}{|c|}{ average } & 902 & 1197 & 7.2 & 45 \\
\hline & \multirow{4}{*}{$\begin{array}{l}\text { Chrome steel: } \\
T=1070{ }^{0} \mathrm{C}, 10 \mathrm{~h}\end{array}$} & 7 & 1 & 800 & 1042 & 9.0 & 53 \\
\hline & & 8 & 2 & 808 & 1066 & 10.2 & 53 \\
\hline & & 9 & 3 & 790 & 945 & 6.4 & 54 \\
\hline & & \multicolumn{2}{|c|}{ average } & 799 & 1018 & 8.5 & 53 \\
\hline
\end{tabular}

For specimens with different modes of diffusion metallization with chromium in comparison with the original specimens, there is a significant increase in strength indicators by about $100 \ldots 280 \mathrm{MPa}$ for ultimate strength and by about $60 \ldots 200 \mathrm{MPa}$ for yield strength. The plasticity characteristics $(\delta, \%$ and $\psi, \%)$ for chrome-plated samples are lower than those for the original ones. This is due to the hardening due to the chromium plating of the steel and the high strength values. Fracture of chromium-plated specimens occurred with localization of deformation and necking. The fracture surface has an uneven matte dark gray appearance, sometimes it has the shape of a cup fracture, which indicates a viscous nature of fracture.

Table 5

Bending test of specimens made of $15 \mathrm{Cr} 12 \mathrm{WNiMoV}$ steel at room temperature

\begin{tabular}{|c|c|c|c|}
\hline Sample condition & $\sigma_{\max }, \mathrm{MPa}$ & Bend angle, degrees & Post-test condition \\
\hline Original & 1312 & $\approx 90$ & Without cracks, overheads \\
\hline Nitrided & 1226 & $\approx 30$ & $\begin{array}{c}\text { Numerous small cracks } \\
\text { on the extended side }\end{array}$ \\
\hline $\begin{array}{c}\text { Chrome steel: } \\
T=1070{ }^{\circ} \mathrm{C}, 4 \mathrm{~h}\end{array}$ & 1849 & $\approx 90$ & Rib tear \\
\hline $\begin{array}{c}\text { Chrome steel: } \\
T=1070{ }^{\circ} \mathrm{C}, 10 \mathrm{~h}\end{array}$ & 1164 & $\approx 45$ & $\begin{array}{c}\text { Crack } 1 / 2 \text { thickness } \\
\text { sample }\end{array}$ \\
\hline $\begin{array}{c}\text { Chrome steel: } \\
T=1100{ }^{\circ} \mathrm{C}, 4 \mathrm{~h}\end{array}$ & 1772 & $\approx 30$ & small tears \\
\hline $\begin{array}{c}\text { Chrome steel: } \\
T=1100{ }^{\circ} \mathrm{C}, 10 \mathrm{~h}\end{array}$ & 1155 & & $\begin{array}{c}\text { Crack } 1 / 2 \text { thickness } \\
\text { sample }\end{array}$ \\
\hline
\end{tabular}

The results of bending tests of specimens made of $15 \mathrm{Cr} 12 \mathrm{WNiMoV}$ steel presented in Table 5 at room temperature showed the following. The surface of the original specimen, stretched during the tests, remained intact, without the appearance of tears and upon deformation of the original specimens at an angle of 90 degrees without the appearance of cracks. The maximum stress at an angle of 90 degrees reached an average of $1312 \mathrm{MPa}$. 
When testing nitrided samples, when the stress reached $800 \ldots 900 \mathrm{MPa}$, numerous small cracks began to appear in the direction of the mandrel. The maximum stress that the nitrided samples withstood on average reached $1226 \mathrm{MPa}$. During the tests, under the action of the load of the sample by the mandrel, deformation (embrittlement) of the surface layer from the inner radius (under the mandrel) occurred. The bending angle at the specified load reached approximately 30 degrees.

Tests of samples chrome-plated for $4 \mathrm{~h}$ at a temperature of $T=1070{ }^{\circ} \mathrm{C}$ showed the following: when the bending angle approaches 90 degrees, distortion (deformation) of the metal occurred on the lateral and external surfaces and a tear appeared on the external (stretching) edge of the sample. The maximum average stress that the samples withstood before the appearance of a rupture is $1849 \mathrm{MPa}$.

Specimens, which were chromium-plated at a temperature of $T=1070{ }^{\circ} \mathrm{C}$ for $10 \mathrm{~h}$, failed after reaching stresses on average $1164 \mathrm{MPa}$. The bending angle was no more than 30 degrees. Cracks developed rapidly to almost $1 / 2$ the thickness of the sample. On the surface of the fracture, a silvery component with a metallic luster prevails - brittle fracture.

Tests carried out on specimens that have undergone chromium plating at $T=1100{ }^{\circ} \mathrm{C}$ for $4 \mathrm{~h}$ have shown that cracks appear when the bending angle becomes close to 45 degrees. In this case, the maximum stress averaged $1772 \mathrm{MPa}$. Before the appearance of small tears on the lateral and external surfaces of the samples, a slight bending of the metal occurred - the localization of deformation, along which the crack began to develop. At the bottom of the samples, I found the presence of a viscous component on the fracture surface of the samples, which indicates the occurrence of plastic deformation processes in the bulk of the samples during testing.

Samples that were chrome plated at $1100{ }^{0} \mathrm{C}$ for $10 \mathrm{~h}$ behaved as follows. During the tests, upon reaching an angle of about 30 degrees and an average stress of $1155 \mathrm{MPa}$, a rapid growth of a crack from the outer surface to half of the specimen thickness occurred. The fracture has a silvery metallic luster, indicating brittle fracture.

\section{CONCLUSIONS}

1. It was found that when chrome plating of 15Cr12WNiMoV steel samples, a diffusion layer with a thickness of 50 to $130 \mu \mathrm{m}$ is formed on them, depending on the conditions of chemical-thermal treatment.

2. It was found that after vacuum activated chromium plating, the chromium content in the surface layer of steel $15 \mathrm{Cr} 12 \mathrm{WNiMoV}$ varies within $56 . .82 \mathrm{wt} . \%$, the rest is iron.

3 . Tests of samples made of $15 \mathrm{Cr} 12 \mathrm{WNiMoV}$ steel for abrasive wear and cavitation showed that after saturation of the steel surface with chromium, its resistance is somewhat inferior to the original material.

4. Comparative tests for heat resistance in air of chrome-plated specimens of steel $15 \mathrm{Cr} 12 \mathrm{WNiMoV}$ at a temperature of $T=900{ }^{\circ} \mathrm{C}$ were carried out. It has been established that the heat resistance of chrome-plated specimens is much higher than that of both the original specimens and those that have undergone furnace nitriding.

5. When testing samples with different modes of diffusion metallization with chromium in comparison with the original samples, a significant increase in strength indicators for ultimate strength and yield strength is noted. The plasticity characteristics for specimens that have undergone chromium plating are lower than those of the original ones.

6 . Bending tests of $15 \mathrm{Cr} 12 \mathrm{WNiMoV}$ steel specimens at room temperature showed that specimens that have undergone vacuum activated chromium plating are less able to withstand such loads.

\section{REFERENCES}

1. G.N. Dubinin. Diffusion chromium plating of alloys. M.: "Mechanical Engineering", 1964, 451 p.

2. A.R. Castle, D.R. Gabe Chromium diffusion coatings // International Materials Reviews. 1999, v. 44, N 2, p. 37-58.

3. R. Bianco, M.A. Rapp. Codeposition of Elements in Diffusion Coatings by the Halide-Activated Pack Cementation Method // Journal of Metals. 1991, p. 6873.

4. A.M. Guryev, B.D. Lygdenov, S.P. Ivanov, et al. New methods of diffusion thermocyclic hardening of the surface of steel products with boron together with titanium and chromium // Fundamental research. 2007. N 10, p. 89-91.

5. S.G. Rudenkiy. Vacuum-activated chromium plating of steel 20 in nanocrystalline powder // Physical surface engineering, 2012, v. 10, N 1, p. 29-35.

6. Method of diffusion saturation of product surface / V.I. Serpent, M. Kartmazov, S. Rudenkiy. Patent for invention No. 98074, C23C 8/00, C23C 12/00Publ. from 10.04.2012. Bulletin No. 7.

7. Device for diffusion saturation of product surface in vacuum / V.I. Serpent, M. Kartmazov, S. Rudenkiy. Patent for invention No. 98087, C23C 8/00, C23C 12/00. Publ. 10.04.2012. Bulletin No. 7.

8. V.I. Zmiy, N.F. Kartsev, N.V. Kovtun, S.G. Rudenkiy. Investigation of the formation processes and properties of chromium-containing diffusion coatings on steels // Sat. Reports of the 1st International Symposium "Vacuum Technologies and Equipment". Kharkiv, 23-27 April 2001, p. 266-268.

9. S.G. Rudenkyi, V.I. Zmij, N.F. Kartzev, A.A. Korneev, A.V. Kunchenko, V.V. Kunchenko, Y.V. Kunchenko, V.G. Marinin, V.I. Kovalenko, M.O. Bortnytska, T.P. Ryzhova, and I.A. Lashenko. Influence of vacuum activated diffusion chroming on mechanical properties of the surface of steel 25X1MF // Problems of Atomic Science and Technology. Series "Physics of Radiation Effect and Radiation Materials Science”. 2020, N 2, p. 132-138.

10. A.A Andreev, V.I. Kovalenko, V.G. Marinin, L.I. Martynenko, V.A. Stolbovoy. Erosion of multilayer vacuum-arc metal-nitride coatings on the base of $\mathrm{Ti}, \mathrm{Zr}$, Cr, Mo under cavitation // Scientific Journal “ScienceRise”. 2016, N 5/2(22), p. 34-39. 


\title{
СВОЙСТВА СТАЛИ 15Х12ВНМФ ПОСЛЕ ВАКУУМНОГО АКТИВИРОВАННОГО ХРОМИРОВАНИЯ ЕЕ ПОВЕРХНОСТИ
}

\author{
С.Г. Руденький, Н.Ф. Карцев, А.А. Корнеев, А.В. Кунченко, Ю.В. Кунченко, В.Г. Маринин, \\ Л.И. Мартыненко, В.И. Коваленко, М.А. Бортницкая, Т.П. Рыжова, И.А. Ляшенко, \\ С.В. Гоженко, Е.А. Крайнюк
}

\begin{abstract}
Проведены исследования свойств образцов из стали 15Х12ВНМФ после вакуумного активированного хромирования при температурах 1070 и $1100{ }^{\circ} \mathrm{C}$ в течение 4 и 10 ч. Установлено, что после химикотермической обработки на образцах формируется диффузионный слой толщиной от 50 до 130 мкм, состоящий из $56 \ldots 82$ вес.\% хрома, остальное - железо. На образцах были проведены металлографические исследования и осуществлены испытания на жаростойкость при $T=900{ }^{\circ} \mathrm{C}$. Установлено, что хромированные образцы по жаростойкости значительно превосходят исходные образцы и азотированные. Проведенные испытания образцов на прочность на разрыв после хромирования показали существенное увеличение прочностных показателей для предела прочности и предела текучести. Характеристики пластичности этих образцов уменьшаются.
\end{abstract}

\section{ВЛАСТИВОСТІ СТАЛІ 15Х12ВНМФ ПІСЛЯ ВАКУУМНОГО АКТИВОВАНОГО ХРОМУВАННЯ ÏÏ ПОВЕРХНI}

\author{
С.Г. Руденький, М.Ф. Карцев, О.О. Корнєєв, О.В. Кунченко, Ю.В. Кунченко, В.Г. Маринін, \\ Л.І. Мартиненко, В.І. Коваленко, М.О. Бортницька, Т.П. Рижова, І.А. Ляшенко, \\ С.В. Гоженко, С.О. Крайнюк
}

\footnotetext{
Проведені дослідження властивостей зразків зі сталі 15Х12ВНМФ після вакуумного активованого хромування при температурах 1070 i $1100{ }^{\circ} \mathrm{C}$ протягом 4 і 10 год. Установлено, що після хіміко-термічної обробки на зразках формується дифузійний шар товщиною від 50 до 130 мкм, що складається 3 $56 . . .82$ ваг.\% хрому, інше - залізо. На зразках були проведені металографічні дослідження й здійснені випробування на жаростійкість при $T=900^{\circ} \mathrm{C}$. Установлено, що хромовані зразки по жаростійкості значно перевершують вихідні зразки й азотовані. Проведені випробування зразків на міцність на розрив після хромування показали істотне збільшення міцностних показників для межі міцності й межі текучості. Характеристики пластичності цих зразків зменшуються.
} 